\title{
ARTICLE
}

Cite this: DOI: $10.1039 /$ xoxxooooox

Received ooth,

Accepted ooth

DOI: $10.1039 / \times 0 x \times 00000 x$

www.rsc.org/

Corresponding Author: A/Prof Andrea Hinwood Centre for Ecosystem Management Edith Cowan University, 270 Joondalup Drive Joondalup 6027 Western Australia Ph 61863045372 e.mail:

a.hinwood@ecu.edu.au

\section{Polychlorinated Biphenyls (PCBs) and Dioxin concentrations in residential dust of pregnant women}

A.L. Hinwood ${ }^{a}$, A. C. Callan ${ }^{a}$, J. Heyworth ${ }^{b}$, D. Rogic ${ }^{c}$, J. de Araujo ${ }^{c}$, R. Crough ${ }^{c}$, G. Mamahit $^{\mathrm{c}}$, N. Piro ${ }^{\mathrm{c}}$, A.Yates ${ }^{\mathrm{c}}$, G. Stevenson ${ }^{\mathrm{c}}$, J. O. Odland, ${ }^{\mathrm{d}}$

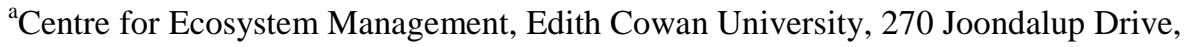
Joondalup, WA Australia

${ }^{\mathrm{b}}$ School of Population Health, The University of Western Australia, 35 Stirling Highway, Crawley WA 6009, Australia

${ }^{\mathrm{c}}$ National Measurement Institute Australia, 105 Delhi Rd, North Ryde NSW 2113

Australia

${ }^{\mathrm{d}}$ Department of Community Medicine, University of Tromse, NO-9037 Tromse, Norway

\begin{abstract}
Polychlorinated biphenyls (PCBs) and dioxins are well known for their persistence in the environment. PCBs can be found in the residential environment long after the use of these chemicals in domestic products and industrial processes has ceased. Dioxins have been assessed in Australia as being of very low concentrations. Despite concerns about residential dust as a source of human exposure to persistent chemicals, there has been limited testing of PCBs and dioxins in dust in Australia. As part of an assessment of maternal exposure to a variety of persistent toxic substances, we analysed 30 residential dust samples from a variety of geographical settings for their dioxin and PCB concentrations. PCBs were found in most samples, the median and range concentrations (pg/g) of dominant congeners of PCB were as follows: PCB118 (315; <35.0 - 29000), PCB105 (130; 14.0 - 16000) and PCB156 (440; <5.00 - 2800). Dioxin concentrations were generally low with median concentrations for total sum of dioxin-like polychlorinated dibenzodioxins (PCDD) and polychlorinated dibenzofurans (PCDF) of $3.75 \mathrm{pg} / \mathrm{g}$ each. There were a very high percentage of non-detects. Concentrations of both PCBs and dioxins were low compared with most studies reporting residential dust concentrations internationally. Age of dwelling and housing type-was the only factors observed to influence both PCB congener concentrations and dioxin isomers in multivariate regression analyses. No other housing or sociodemographic variables, including proximity to industry, were important predictors.
\end{abstract}




\section{ARTICLE}

\section{Introduction}

Polychlorinated biphenyls (PCBs) along with dibenzodioxins and dibenzofurans (dioxins) are persistent organic pollutants (POP) that result largely from anthropogenic activities. There are 209 individual congeners of PCBs with approximately 130 of those congeners having widespread anthropogenic use prior to $1977\left(\mathrm{ATSDR}^{1}\right)$. The term dioxin relates to polychlorinated dibenzodioxins (PCDD) compounds (chlorinated derivatives of $p$-dibenzodioxin) plus polychlorinated dibenzofurans (PCDF) ${ }^{23}$.

PCBs were previously used in domestic products such as carpets and upholstery, paint, sealants, coolant, lubricants, pesticides and electronic equipment, which resulted in the extensive distribution of PCBs in the environment ${ }^{1,2}$. Other sources of these pollutants include the burning of waste in industrial incinerators and leakage from sealants and paint in older buildings ${ }^{2,4}$.

Although the manufacture, processing and distribution of PCBs has been prohibited in almost all industrial countries since the 1980s, their entry into the environment still occurs, especially due to improper disposal practices or leaks in electrical equipment and hydraulic systems which may still be in use ${ }^{2}$. They are found in soils, dust, biota and hence food due to their persistence in environmental media ${ }^{5}$. In Australia, PCBs were never manufactured and importation was banned in 1975 (www.npi.gov.au).

PCBs are largely insoluble in water with the main exposure pathways in humans being the ingestion of food and inhalation of dust ${ }^{2,6,7}$. Based on the evidence in animal studies PCBs have been classified as probable human carcinogens (2A) with selected congeners considered to cause cancer (Group 1).

(http://monographs.iarc.fr/ENG/Classification/).

Dioxins are formed from activities such as industrial incineration and power generation, and also natural processes such as volcanic activity and forest fires which contribute to the presence of dioxins in the air, soil and sediment ${ }^{5}$.

Pentachlorophenol (PCP) in textiles has also been identified as a source of PCDD/Fs ${ }^{9}$. Products using these textiles and other pesticides reported to contain PCDD/F could therefore contribute these compounds to dust in homes ${ }^{3,9}$.

The toxicity of a dioxin is determined by the number and configuration of chlorine $(\mathrm{Cl})$ atoms in the compound, with 2,3,7,8-tetrachlorodibenzodioxin (TCDD) being the most toxic dioxin compound ${ }^{8}$. Whilst there are many PCB congeners, 12 of these are described as having dioxin-like characteristics and have either one (mono-ortho) or no (nonortho) chlorine atoms at the ortho positions. Dioxins and the dioxin-like PCBs share the characteristic of binding to the aryl hydrocarbon receptor (AhR), an intracellular liganddependent transcription factor found in many tissues, although the toxicity of the dioxins and dioxin-like PCBs varies $^{8}$. Any dioxin compound with a toxic response similar to TCDD is referred to as a dioxin-like compound and the toxicity of these compounds is expressed relative to TCDD by Toxic Equivalence Factors ${ }^{8}$. A toxic equivalence factor (TEF) has been assigned to individual PCB and dioxins congeners based on results from in vitro and in vivo studies ${ }^{8}$. From the individual concentrations of dioxin-like compounds and their TEF, a Toxic Equivalence (TEQ) can be assigned to samples.

As with PCBs, the main exposure pathways of humans to dioxins are through the ingestion in food and the inhalation of contaminated dust particles ${ }^{2,10,11}$. Other pathways include ingestion of via soil contaminated with PCBs and exposure via soil and dermal contact. ${ }^{12,13,14}$. In terms of exposure to PCBs in dust exposure can occur through accidental ingestion, dermal contact and inhalation of re-entrained dust. In the home, where most people spend over $80 \%$ of their time, residents may be exposed to PCB and dioxin concentrations that may increase the potential for adverse health effects which include adverse birth outcomes, neurodevelopmental effects and leukaemia ${ }^{1,5,15}$. Pregnant 
women and children may be more vulnerable to the effects of persistent organic pollutants and so are considered an at-risk group ${ }^{5}$.

This opportunistic study aimed to determine the concentrations of dioxins and dioxin-like PCBs in the residential homes of pregnant women. Demographic and housing characteristics were explored for their contribution to measured concentrations.

\section{Methods}

This study was a cross-sectional assessment of residential dust concentrations of Dioxins and PCBs. Dust samples were provided by participants of the Australian Maternal Exposure to Toxic Substances (AMETS) study during the third trimester of their pregnancy ${ }^{16}$. Thirty samples were randomly selected from a possible 167 samples across the State of Western Australia.

Ethics approval was obtained from the Edith Cowan University Human Research Ethics Committee, WA Country Health Service, St John of God Health Care (Subiaco and Bunbury), Joondalup Health Campus and King Edward Memorial Hospital. All participants provided written informed consent.

\subsection{Data Collection}

Each participant of the AMETS study completed a questionnaire which included information about their home, furniture and proximity to industry and roads (Supplementary data Table S1). Participants also collected a sample of dust from their vacuum cleaner.

\subsection{Sample Collection and Preparation}

The collection of dust is described in Stasinska et al., ${ }^{17}$ and is summarised here. Participants were instructed to empty the contents of their vacuum cleaner into a provided plastic bag labelled with the participant code and date. Participants then posted the dust samples via Australia Post, directly to Edith Cowan University for storage and analysis.

The dust samples were received in individual plastic bags and each sample was mixed thoroughly within the plastic bag before being air dried in the laboratory for a minimum of 48 hours. The dried samples were individually shaken in a closed sifting pan to homogenise the $<600 \mu \mathrm{m}$ fraction. Particles $>$ $600 \mu \mathrm{m}$ in size were removed and disposed of accordingly. To minimise cross contamination between individual samples, the sieves were cleaned with a brush and fresh paper tissue and rinsed with acetone.

\subsection{Analysis of PCDDs, PCDFs \& PCBs:}

Analysis of dioxins and dioxin-like PCBs was undertaken at the National Measurement Institute, New South Wales. High resolution mass spectrometry was used to determine PCDDs, PCDFs \& the dioxin-like PCBs concentrations (pg/g) based on US EPA methods 8290, 1613B, 1668B \& 3545 (USEPA $^{18,19,20,21}$ ). The dust samples were dried with an inert drying agent, $20 \mathrm{~g}$ accurately weighed, homogenised then spiked with $15{ }^{13} \mathrm{C}$ isotopically labelled PCDD/F's and $12{ }^{13} \mathrm{C}$ isotopically-labelled DL PCBs in order to act as surrogates. Toluene was used in the Dionex ASE 100 \& ASE 300 auto extraction systems $\left(150^{\circ} \mathrm{C}, 1500 \mathrm{psi}\right)$ to extract, concentrate and split all samples. Initial clean up included acid backextraction and gel permeation chromatography to remove sulphur contamination (as per EPA method 3640A). Acidic/basic/neutral silica gel, alumina and activated carbon column clean-up was undertaken using FMS Power-Prep. Non-ortho substituted PCBs were separated from Mono-ortho substituted PCBs and PCDD/Fs. Two PCDD/Fs and four isotopically-labelled PCBs were added to each extract prior to analysis to determine surrogate recoveries.

The qualitative/quantitative analysis of PCDD/Fs, Non-ortho substituted PCBs and Mono-ortho substituted PCBs (congeners) was undertaken using a HP 6890 High-resolution gas chromatograph (coupled with a Finnigan Mat A200S auto sampler), a Finnigan MAT 95XL High-resolution mass spectrometer (HRMS) (maintained at >10,000) and a computerised data system in accordance with US EPA methods 1613/1668. PCDD/Fs and PCB congener analyte identification occurred when two ions, within the allowable abundance ratio were detected within the prescribed retention time window. The isotopically labelled surrogates were used for quantification of PCDD/Fs and PCBs. Single column 
analysis on HRMS allowed for co-elution of interfering compounds, so a second column was used for Mono-ortho substituted PCBs and several dioxin/furans. The list of compounds analysed in dust in this study and the respective detection limits achieved for this study are shown in Supplementary data Table S2.

\subsection{Statistical Analysis}

PCB and dioxin concentrations were highly skewed and the data were $\log$ transformed prior to analysis. Statistical analysis was undertaken using SPSS version 21 (IBM). All samples recording less than detectable concentrations were assigned half the detection limit. Only those congeners with $>70 \%$ detectable concentrations were investigated for factors or housing characteristics that may influence dust PCB and dioxin concentrations. Pearson correlation coefficients (continuous variables), Spearman rank correlation and Kruskall Wallis tests (categorical variables) were used to assess the association of household and regional characteristics collected from questionnaire information on dust concentration data. Linear regression models were run on natural log transformed total concentrations of PCBs and Dioxins using forward entry method based on a probability $\mathrm{F}$ entry of 0.05 . Predictors considered for model inclusion were variables collected via Questionnaire (Supplementary data)those which included questions on factors identified in previous studies as being important for the presence of PCBs and dioxins. The variables included in the models identified from-were those the literature and also those-found to be significant in univariate analyses $(\mathrm{p}<0.05)$.

\section{Results}

The dust samples were collected from participants who lived in mainly brick and tile homes in urban areas away from industry (Table 1). Over 60 percent of homes were older than 10 years with twenty percent older than 50 years (Table 1 ). Many residents had undertaken renovation over the past year (55\%). All participants were non-smokers and none reported a family member or visitor smoking inside the home, however $46 \%$ of participants reported visitors smoking outside (Table 1).
Residential dust samples had Total PCB concentrations ranging from less than the detection limit to $54,600 \mathrm{pg} / \mathrm{g}$. The congener with the highest concentration was PCB118, followed by PCB156 and PCB105 (Table 2).

Table 1. Housing Characteristics ( $n=30$ unless otherwise specified)

\begin{tabular}{|c|c|}
\hline Characteristic & $\begin{array}{l}\text { \% of } \\
\text { samples/ } \\
\text { responses }\end{array}$ \\
\hline \multicolumn{2}{|l|}{ Age of home (years) $(n=29)$} \\
\hline$<2$ years & 6.9 \\
\hline $2-10$ years & 24.1 \\
\hline $10-50$ years & 48.3 \\
\hline$>50$ years & 20.7 \\
\hline \multicolumn{2}{|l|}{ Type of Home } \\
\hline House & 93.3 \\
\hline Duplex/townhouse/villa & 3.3 \\
\hline Flat/Unit/ apartment & 3.3 \\
\hline Urban Dwelling (\% of participants) & 40.0 \\
\hline Rural and Outback (\% of participants) & 60.0 \\
\hline Main Building materials & \\
\hline Brick/brick veneer/tile & 70.0 \\
\hline Timber & 13.3 \\
\hline Fibrocement/asbestos & 16.7 \\
\hline $\begin{array}{l}\text { Percentage of participants reporting } \\
\text { living within } 1 \mathrm{~km} \text { of industry) }\end{array}$ & 30.8 \\
\hline \multicolumn{2}{|l|}{ Main Heating source } \\
\hline Electric & 3.3 \\
\hline Gas & 40.0 \\
\hline Wood & 13.3 \\
\hline $\mathrm{RC}$ air conditioner & 40.0 \\
\hline No heating & 3.3 \\
\hline Reported Renovations in past year (yes) & 55.2 \\
\hline Reported Visitor Smoking outside & 46.7 \\
\hline
\end{tabular}




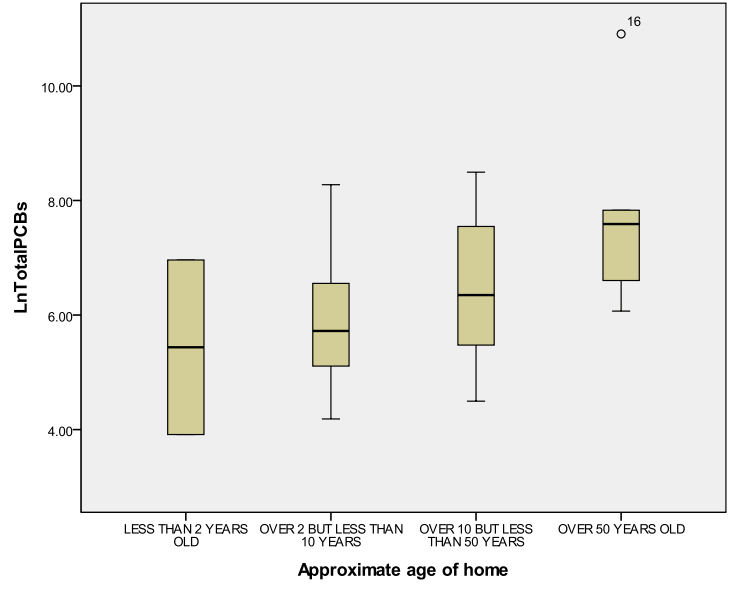

Figure 1. Natural log of Sum of PCBs (pg/g) by categories of age of home.

The influence of household and regional characteristics on dust PCB concentrations was examined. Each individual PCB and total PCBs were used in the analysis of these relationships, with only age of home shown to be important, with increased age of home associated with increased dust PCB concentrations (Figure 1).

The regression analysis undertaken revealed that approximate age of home accounted for nearly $18 \%$ in the variation in total PCB concentrations ( Supplementary data Table S3). No other factors were identified that significantly influenced either individual PCB congeners or total PCB concentrations.

The PCB congener profiles were examined and similar patterns were observed across all samples indicating widespread sources across Western Australia (Figure 2). The PCB profile was dominated by Mono-ortho PCB congeners, namely PCB-118 (42-59\%), PCB-105 (20-30\%), followed by HxPCB-156 (3-13\%). PCB-77 was the most dominant Nonortho PCB with some variation (2-17\%) due to non-detection in some dust samples.

The concentrations of dioxins were low with a high percentage of non-detects for individual congeners (Table $3,4)$. The PCDD congener profiles (Figure 3) were similar for all dust samples across the urban and rural sites indicating similar contamination sources. The samples were dominated by Octachlorodibenzo-p-dioxin (OCDD) (62-94\%) followed by 1,2,3,4,6,7,8-HpCDD (5-29\%) congeners. There were two slightly different samples; No 15 (urban) and sample No 24 (rural) where additional congeners were detected (0.1-24\%), of 1,2,3,6,7,8-HxCDD,1,2,3,7,8,9-HxCDD, 1,2,3,4,7,8-

HxCDD and 1,2,3,7,8-PeCDD suggesting they may each have a local source compared with other samples (Figure 3).

There was greater variation in PCDF congener profiles (Figure 4), which may indicate several local sources such as combustion or industrial emissions, although distance to road or industry was not observed to be a contributor to the dust concentrations.

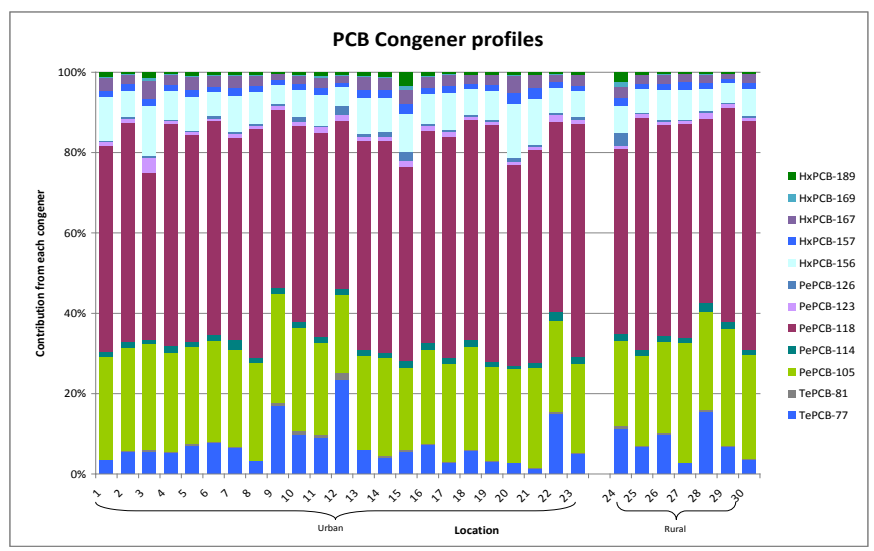

Figure 2 Contribution of $P C B$ congeners to total mass of dioxinlike-PCBs $(<D L$ samples recorded as $D L)$.

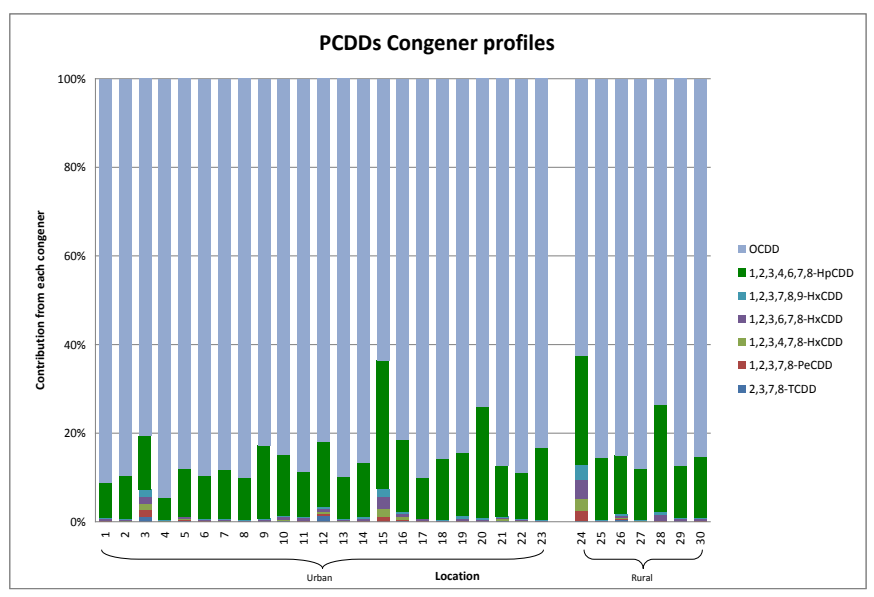

Figure 3 Contribution of PCDD congeners to total mass of PCDDs ( $<$ DL samples recorded as DL). 


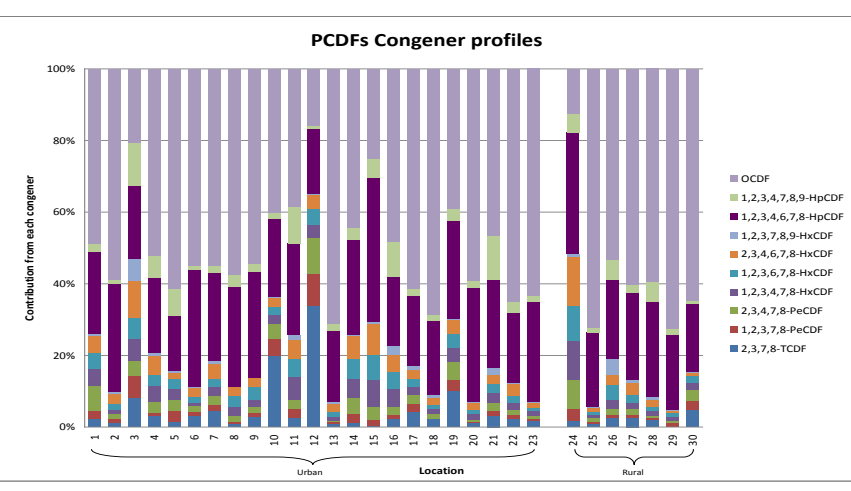

Figure 4 Contribution of PCDF congeners to total mass of PCDFs ( $<$ DL samples recorded as DL).

The PCDF congener profile was dominated by OCDF (13$72 \%)>$ 1,2,3,4,6,7,8-HpCDF (15-40\%) > 2,3,4,6,7,8-

HxCDF (2-13\%). Sample No 24 (rural) once again differs from the rest of the dust samples by having the lowest proportion of OCDF congener (13\%).

Associations with household and regional characteristics were examined and it was found that age of home was important for Total TCDF, HxCDF and HpCDF (Supplementary data Table S3).

Table 2: Median, Geometric Mean and Range for Non-ortho and Mono-ortho substituted PCB congeners (pg/g)

\begin{tabular}{|c|c|c|c|}
\hline Compound & $\begin{array}{l}\text { Median } \\
\text { (range) }\end{array}$ & $\begin{array}{l}\text { \% } \\
\text { Samples } \\
\text { below } \\
\text { DL }\end{array}$ & $\begin{array}{l}\text { TEF(WHO } \\
\text { 2005) }\end{array}$ \\
\hline \multicolumn{4}{|l|}{$\begin{array}{c}\text { Non-ortho } \\
\text { substituted } \\
\text { PCB's }\end{array}$} \\
\hline TePCB77 & $\begin{array}{c}39.5 \\
(<1.5-3710)\end{array}$ & 3.3 & 0.0001 \\
\hline TePCB81 & $\begin{array}{c}1.70 \\
(<1.0-170)\end{array}$ & 33.3 & 0.0003 \\
\hline РePCB126 & $\begin{array}{c}4.00 \\
(<1.0-82.0)\end{array}$ & 26.7 & 0.1 \\
\hline HхРCB169 & $\begin{array}{c}<1.0 \\
(<1.0-9.0)\end{array}$ & 76.7 & 0.03 \\
\hline \multicolumn{4}{|l|}{$\begin{array}{c}\text { Mono-ortho } \\
\text { substituted } \\
\text { PCB's }\end{array}$} \\
\hline PePCB105 & $\begin{array}{c}130 \\
(14-16000)^{*}\end{array}$ & 0 & 0.0003 \\
\hline PePCB114 & $\begin{array}{c}9.38 \\
(0.5-1060)^{*}\end{array}$ & 0 & 0.0003 \\
\hline PePCB118 & $\begin{array}{c}315 \\
(<35.0- \\
29000) \\
\end{array}$ & 3.3 & 0.0003 \\
\hline PePCB123 & $\begin{array}{c}6.55 \\
(<1.0-550) \\
\end{array}$ & 6.7 & 0.0003 \\
\hline
\end{tabular}

\begin{tabular}{|c|c|c|c|}
\hline HxPCB156 & $\begin{array}{c}44.0 \\
(<5.0-2790)\end{array}$ & 6.7 & 0.0003 \\
\hline HxPCB157 & $\begin{array}{c}10.2 \\
(<1.0-550)\end{array}$ & 10.0 & 0.0003 \\
\hline HxPCB167 & $\begin{array}{c}16.5 \\
(<1.00-720)\end{array}$ & 3.3 & 0.0003 \\
\hline HxPCB189 & $\begin{array}{c}3.6 \\
(<0.30-140)\end{array}$ & 6.7 & 0.0003 \\
\hline TotalSum & $\begin{array}{c}572 \\
(<D L- \\
\text { PCBs }\end{array}$ & & \\
\hline
\end{tabular}

Concentrations of PCDD and PCDF tended to be higher in the dust samples collected from the homes of participants who reported residing in proximity to industry, but this relationship was not statistically significant (Supplementary data Table 3).

Table 3 Chlorinated dibenzo-p-dioxin concentrations (pg/g) $(\mathbf{n}=30)$

\begin{tabular}{|l|l|l|}
\hline Compound & Median(Range) & $\begin{array}{l}\text { \% samples } \\
\text { below DL }\end{array}$ \\
\hline $2,3,7,8-\mathrm{TCDD}$ & $<0.10(<0.10-4.80)$ & 70.0 \\
\hline $1,2,3,7,8-\mathrm{PeCDD}$ & $<0.50(<0.50-13.0)$ & 56.7 \\
\hline $1,2,3,4,7,8-\mathrm{H} \times C D D$ & $<0.50(<0.50-23.0)$ & 73.3 \\
\hline $1,2,3,6,7,8-\mathrm{H} \times C D D$ & $1.75(<1.0-37.0)$ & 43.3 \\
\hline $1,2,3,7,8,9-\mathrm{H} \times C D D$ & $<1.50(<1.50-21.0)$ & 70.0 \\
\hline $1,2,3,4,6,7,8-\mathrm{HpCDD}$ & $49.0(<10.0-590)$ & 16.6 \\
\hline OCDD & $325(<20.0-2960)$ & 3.33 \\
\hline Total TCDD & $1.50(0.40-60.0)$ & 0 \\
\hline Total PeCDD & $3.80(0.4-160)$ & 0 \\
\hline Total HxCDD & $20.0(<1.5-450)$ & 13.3 \\
\hline Total HpCDD & $99.0(2.5-1090)$ & 3.3 \\
\hline
\end{tabular}

Table 4 Chlorinated dibenzofuran concentrations (pg/g) (n=30)

\begin{tabular}{|l|l|l|}
\hline Compound & $\begin{array}{l}\text { Median } \\
\text { (Range) }\end{array}$ & $\begin{array}{l}\text { \% samples } \\
\text { below DL }\end{array}$ \\
\hline $2,3,7,8-\mathrm{TCDF}$ & $<2.00(<2.0-30.0)$ & 73.3 \\
\hline $1,2,3,7,8-\mathrm{PeCDF}$ & $<1.0(<1.00-13.0)$ & 73.3 \\
\hline $2,3,4,7,8-\mathrm{PeCDF}$ & $<3.0(<3.0-32.0)$ & 73.3 \\
\hline $1,2,3,4,7,8-\mathrm{HxCDF}$ & $<3.0(<3.0-64.0)$ & 80.0 \\
\hline $1,2,3,6,7,8-\mathrm{HxCDF}$ & $<4.0(<4.0-57.0)$ & 83.3 \\
\hline $1,2,3,7,8,9-\mathrm{HxCDF}$ & $<0.3(<0.3-4.40)$ & 1.00 \\
\hline $2,3,4,6,7,8-\mathrm{HxCDF}$ & $<3.0(<3.0-74.0)$ & 13.3 \\
\hline
\end{tabular}




\begin{tabular}{|l|l|l|}
\hline $1,2,3,4,6,7,8-\mathrm{HpCDF}$ & $<20.0(<20.0-340)$ & 60 \\
\hline $1,2,3,4,7,8,9-\mathrm{HpCDF}$ & $<4.0(<4.00-46.0)$ & 86.7 \\
\hline OCDF & $18.5(<5.0-290)$ & 26.7 \\
\hline Total TCDF isomers & $5.85(<2.0-660)$ & 10.0 \\
\hline Total Pe CDF & $3.80(0.45-390)$ & 30.0 \\
\hline Total Hx CDF & $5.70(<2.0-640)$ & 26.7 \\
\hline Total HpCDF & $9.45(0.5-530)$ & 6.7 \\
\hline
\end{tabular}

the US, at what were considered to be background concentrations.

PCDD/F congener profiles of soil samples around Australia are dominated by OCDD, which contributes $60-90 \%$ of total PCDD/F congener profiles, with HpCDD the next most dominant congener ${ }^{27}$. A similar profile was identified in household dust in this study. The interpretation of the congener profiles in this study has shown that for most homes tested, the PCDD/Fs and dioxin like-PCBs contamination may be from similar, diffuse sources, but identified individual samples with different profiles, indicating local sources. The

\section{Discussion}

The results confirm the presence of PCBs in residential homes, and hence potential for exposure, long after the use of these chemicals in products have ceased and the increased concentrations in older homes supports the work of other researchers ${ }^{22}$. Concentrations in this study (collected between 2009 and 2012) were low compared with concentrations of

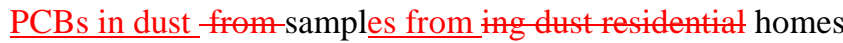
during from_similar time periods (2006 and 2008) in Canada, New Zealand, the UK and the USA ${ }^{6,22}$. The concentrations of both PCBs and dioxins were however similar to those reported by Tue et al., ${ }^{14}$ who also used participant collected dust in New York State USA.

The dominant PCB in this study was PCB118, as has been found in other studies ${ }^{24}$. Whitehead et al., ${ }^{23}$ sampled carpet dust and reported PCB118 concentrations that were nearly 10 times greater than the concentrations in this study.and PCB105 concentrations were also reported to be-higher in researcher collected carpet dust in the Whitehead et al., $\underline{\text { study }^{23}}$. Knobeloch et al., ${ }^{22}$ also reported higher concentrations in US homes and an increased concentration in older homes (predominantly built between 1959 and 1970, following which concentrations decreased. Concentrations of PCBs in this study were also lower than those reported in classrooms and outdoor environments ${ }^{3,10}$.

The dioxin concentrations for the different congeners were also low with most congeners below the limit of detection. Concentrations were low compared with most studies reviewed ${ }^{6,14,25}$ and also lower than those of the study of O’Connor and Sabrsula ${ }^{26}$ which analysed dust from houses in results are consistent with the findings of other researchers where the most abundant isomer OCDD has been reported due to their presence in soils and from atmospheric deposition ${ }^{28}$. The finding of increased dioxin concentrations with age of home was interesting given these substances have traditionally been reported to be associated with emissions from combustion and hence diffuse-sources. However PCDDs have also been identified as being associated with pesticides which may have degraded over time to produce dioxins which have resulted in increasing concentrations in residential dust ${ }^{3}$.

In a ranking of indoor semi- volatile compounds in dust in homes based on literature reported toxicity, Bonvallot et al., ${ }^{7}$, considered PCBs found in household dust a risk factor for infants and children, although the concentrations used in the ranking were those by Harrad et al. ${ }^{6}$ which were substantially higher than those reported here.

This study was limited by the small sample size and cross sectional design as well as the lack of repeated measurements. The use of participant collected dust and a 600 $\mu \mathrm{m}$ sieve fraction during sample preparation may have underestimated concentrations as smaller size fractions are associated with higher concentrations ${ }^{29}$. Compared with other studies, the size fraction of dust analysed in this study was larger $(600 \mu \mathrm{m}$ compared with a variety of mesh sizes down to150 $\mu \mathrm{m}$ used in other studies $6,14,15,23$. 


\section{Concluding Remarks}

PCBs and dioxins were found in household dust in homes of non-occupationally exposed pregnant women. The concentrations were low and may have been underestimated due to the larger sieve size used and the use of participant collected vacuum dust. To enable more definitive comparisons with other studies and to aid in the application of this data to an assessment of risk, the use of standard collection methods, dust size fraction and preparation and analysis should be undertaken.

The concentrations of PCBs and dioxins found in household dust were low in this study-and were unlikely to be an important source of exposure for pregnant women compared, based on a comparison-with concentrations reported in the international literature.

\section{Acknowledgements}

This study was funded by an ARC linkage grant in partnership with the Arctic Monitoring and Assessment Program (AMAP). The ARC was not involved in the design, conduct or reporting on this study. The research team would like to thank all participants who provided samples.

\section{References}

1. Agency for Toxic Substances and Disease Registry (ATSDR) 2000. Atlanta, GA USA. http://www.atsdr.cdc.gov/toxprofiles/tp17.pdf

2. K. Srogi, Environ Chem Lett, 2008, 6,1-28

3. A, Franzblau, L. Zwica, K. Knutson, Q. Chen, S.Y. Lee, B. Hong, P. Adriaems, A. Demond, D. Garabrant, B. Gillespie,J. Lepkowski, W. Luksemburg, M. Maier, and T. Towey, 2009 Journal of Occupational and Environmental Hygiene, 6,188-199.

4. C. Tlustos, M. Sheridan, D. O’Sullivan, W. Anderson, A. Flynn. Food Additive Contamination, 2012, 29(1), 128-138
5. D.O. Carpenter, Reviews Environmental Health, 26(1), 61-69.

6. S. Harrad, C. Ibarra, M. Robson, L. Melymuk, X. Zhang, M. Diamon, J. Douwes, Chemosphere, 2009, 76(2), 232-238.

7. N. Bonvallot, C. Mandin, F. Mercier, B. Le Bot, and P. Glorennec, Indoor Air, 2010 20,458-472.

8. M. Van den Berg, L.S. Birnbaum, M. Denison, M. De Vito, W. Farland, M. Feeley, H. Fiedler, H. Halansson, A. Hanberg, L. Haws, M. Rose, S. Safe, D. Schrenk, C. Tihyama, A. Tritscher, J. Tuomisto, M. Tysklind, N. Walers, R.E. Peterson, Toxicol Sci, 2006, 93(2), 223-241.

9. M. Horstmann, and M.S. McLachlan, Organohalogen Compounds, 1994, 20, 251-254.

10. S. Harrad, E. Goosey, J.K. Desborough, and A. Covaci A. Environ Sci Technol. 2010, 44, 4198-4202

11. L. Roosens, M.A. Abdallah, S. Harrad, H.Neels, A. Covaci. Environ Sci Technol, 2010, 44(8), 2870-2875

12. G. Suzuki, H. Takigami, K. Nose, S. Takahashi, M. Asari, and SI. Sakai, Environ Sci Technol, 2007, 41, 1487-1493.

13. R.F. Herreck, M.D. McClean, J.D. Meeker, L.K. Baxter, and G.A. Weymouth. Environmental Health Perspectives, 2004, 117, 1051-1053

14. T.M. Tue, G. Suzuki, S. Takahashi, K. Kannan, H. Takigami, and S. Tanabe,. Environmental Pollution, 2013, 181,75-80.

15. M.H. Ward, T.S. Colt, C. Metayer, R.B. Gunier, J. Lubin, V. Crouse, M.G. Nishioka, P. Reynolds, P.A. Buffer, Environmental Health Perspectives, 2009, 117(6), 1007-1013.

16. A.L. Hinwood, A.C. Callan, M. Ramalingam, M. Boyce, J. Heyworth, P. McCafferty, J.O. Odland. Environmental Research, 126, 118-124.

17. Stasinska, A.Reid, A. Hinwood, G Stevenson, A. Callan, J.O. Odland, J. Heyworth. Chemosphere, 2013, 91, 187-193.

18. USEPA, 1997 US EPA Method 1613, http://water.epa.gov/scitech/methods/cwa/organics/dioxins/ upload/2007 $07 \quad 10$ methods method dioxins 1613.pdf (accessed July 2014)

19. USEPA 2007a. US EPA Method 8290A http:/www.epa.gov/osw/hazard/testmethods/sw846/pdfs/8290a.p df (accessed July 2014)

20. USEPA,2007b US EPA Method 3545A http:/www.epa.gov/epawaste/hazard/testmethods/sw846/pdfs/354 5a.pdf (accessed July 2014)

21. USEPA,2008 US EPA Method 1668B http:/water.epa.gov/scitech/methods/cwa/bioindicators/upload/20 09_01_07_methods_method_1668.pdf (accessed July 2014)

22. L. Knobeloch, M. Turyk, P. Imm, H. Anderson. Chemosphere, 2012, 86(7), 735-740

23. T.P. Whitehead, J.R. Nuckols, M.H. Ward, and S.M. Rappaport, Emerging themes in Epidemiology. 2012, 9,2. http://www.etconline.com/content/9/1/12.

24. M. Kohler, M. Zennegg, and R. Waeber, Environ Sci Technol, 2002, 36,4735-4740. 
25. Y. Kang, K-C. Cheung, Z-W. Cai, and M.H. Wong. Ecotoxicology and Environmental Safety, 2011, 74,947-952.

26. R. O’Connor and J. Sabrsuka, J. Environmental Forensics 2005, 6, 283-287

27. J. Müller, K. Mülle, M. Goudkamp, M. Mortimer, and D. Haynes . Department of Environment and Heritage. Technical report No. 5, 2004 1-42.

28. N.M. Tue, G. Suzuki, S. Takahashi, T. Isobe, P.T.K. Trang, P.H. Viet, S. Tanabe. Env Sci Technol, 44, 9195-9200.

29. W. Wang, M.J. Huang, J.S. Zheng, K.C. Cheung, M.H. Wong. Sci Total Environ, 2013, 463-464, 1201-1209. 